ks. Andrzej Żądło

\title{
Liturgia i formy pobożności ludowej w adwencie w świetle "Dyrektorium o pobożności ludowej i liturgii”
}

Sobór Watykański II wyraźnie poucza o prymacie liturgii nad innymi formami pobożności ludu Bożego. Przedstawia ją bowiem jako „szczyt, do którego zmierza działalność Kościoła, i zarazem jako źródło, z którego wypływa cała jego moc" (KL 10). Niemniej Sobór uczy, że życie duchowe chrześcijan „nie ogranicza się do udziału w samej liturgii” (KL 12), ale zasilane jest nabożeństwami chrześcijańskiego ludu, szczególnie tymi, które sprawuje się w zgodzie z przepisami Kościoła, zwłaszcza wprowadzonymi przez biskupów (KL 13). Ojcowie soborowi, podkreślając potrzebę sprawowania nabożeństw „zgodnie ze zwyczajami lub prawnie zatwierdzonymi księgami” (KL 13), zarysowali też pole teologicznego i duszpasterskiego rozumienia nabożeństw, kiedy wyraźnie zalecili takie ich uporządkowanie, ,,aby były zgodne ze świętą liturgią, z niej niejako wypływały i do niej wiernych prowadziły. Liturgia bowiem ze swej natury znacznie je przewyższa" (KL 13).

W dniach od 26 do 28 września 2001 roku odbyło się Zebranie Plenarne Kongregacji Kultu Bożego i Dyscypliny Sakramentów, na którym dokonano zatwierdzenia „Dyrektorium o pobożności ludowej i liturgii”, a więc dokumentu, w którym rozważa się związki łączące liturgię z pobożnością ludową, przedstawiając zasady, jakie tymi związkami powinny kierować, oraz proponując wskazania mające zagwarantować owocne przeżywanie nabożeństw w Kościołach partykularnych zgodnie z lokalną tradycją.

14 grudnia 2001 roku Dyrektorium to uzyskało papieską zgodę na opublikowanie i na jej podstawie zostało 17 grudnia 2001 roku promulgowane przez Kongregację Kultu Bożego i Dyscypliny Sakramentów ${ }^{1}$. Treść dokumentu zgrupowana jest w dwie części, obejmujące osiem rozdziałów i poprzedzone przesłaniem Jana Pawła II do Zebrania Plenarnego Kongregacji,

${ }^{1}$ Opublikowane zostało w kwietniu 2002 roku przez Libreria Editrice Vaticana (Città del Vaticano). Polskie tłumaczenie (opracowane przez ks. J. Srokę) ukazało się w Poznaniu w roku 2003 (dalej: DPLiL). 
Dekretem Kongregacji, a także wstępem. Obie części zamyka zakończenie oraz indeksy: tekstów biblijnych, imion i indeks rzeczowy.

Część pierwsza zarysowuje zasadnicze linie związków między liturgią i pobożnością ludową, jakie zostały nakreślone przez historię (rozdz. 1), nauczanie Kościoła (rozdz. 2) i teologię (rozdz. 3). Część druga natomiast zapoznaje ze wskazaniami, jakie należy zachować, by zapewnić należytą harmonię między pobożnością ludową i liturgią na następujących odcinkach:

- roku liturgicznego (rozdz. 4),

- czci okazywanej Matce Bożej (rozdz. 5),

- czci okazywanej aniołom, świętym i błogosławionym (rozdz. 6),

- kultu zmarłych (rozdz. 7),

- nawiedzania sanktuariów i odbywania pielgrzymek (rozdz. 8).

Ponieważ omawiane Dyrektorium obejmuje szeroką problematykę, co widać już po samym zestawieniu zawartości poszczególnych rozdziałów, trudno byłoby się nim zająć przekrojowo w ramach jednego tylko studium. Materiał zawarty w tym dokumencie i ranga poruszanej przez niego problematyki domagać się będzie wielu jeszcze opracowań, które będą wspomagać wysiłki konieczne dla zachowania poprawnych proporcji między tymi dwoma typami wyrazu wiary ludu Bożego, z których pierwszym jest liturgia, tworząca centrum życia kościelnego, drugim zaś formy pobożności ludowej, odnajdujące swe naturalne ukoronowanie w liturgii i do niej też prowadzące, przy koniecznym wsparciu ze strony odpowiedniej katechezy². W związku z powyższym czynimy przedmiotem niniejszego artykułu tylko jeden z tematów opublikowanego niedawno Dyrektorium, a mianowicie ten, który dotyka kwestii związków, jakie zachodzą między liturgią a formami pobożności ludowej w adwencie. Temat ten mieści się w treści czwartego rozdziału Dyrektorium, noszącego tytuł „Rok liturgiczny i pobożność ludowa” (DPLiL 96-103).

Geneza i teologia adwentu oraz formy uprawianej w nim pobożności ludowej

Rok liturgiczny to taka struktura czasowa, w ramach której Kościół celebruje zbawcze dzieło swego Boskiego Oblubieńca przez liturgiczne wspominanie różnych jego aspektów w określone dni, a także okresy całego roku, odsłaniając stopniowo całe misterium Chrystusa, ,począwszy od wcielenia i narodzenia aż do wniebowstąpienia, do dnia Pięćdziesiątnicy oraz do oczekiwania błogosławionej nadziei i przyjścia Pana” (KL 102). Z głębokiego przekonania, że z Kościołem nieustannie obecny jest Jezus (por. Mt 28, 20) - odwieczne Słowo Ojca, wcielone w łonie Maryi (por. J 1, 1. 14) i narodzone w Betlejem (por. Mt 2, 1; Łk 2, 1-7), jak również 
z pewności, że spełni się również zapowiedź o Jego powtórnym przyjściu na świat, zrodziła się potrzeba wydzielenia w roku liturgicznym specjalnego okresu, który by przypominał o potrzebie powszechnej gotowości na spotkanie z Panem, już obecnym i wciąż przychodzącym. W takim klimacie doszło do powstania liturgicznego czasu, określanego jako adwent.

\section{GENEZA ADWENTU}

Samo pojęcie „adwentu” wywodzi się z łacińskiego adventus (przyjście, przybycie) i ma początek w czasach przedchrześcijańskich. W starożytności rzymskiej nazywano tak praktykę corocznego wystawiania na widok publiczny posągów bóstw w przeznaczonych do tego miejscach kultu, na znak ich przybycia do ludzi. Termin ten mógł też oznaczać objęcie władzy przez nowo wybranego cesarza. Podobnie nazywano dzień uroczystej wizyty władców w jakimś mieście. Odpowiednikiem łacińskiego adventus były greckie określenia: epiphanía, parousía, epidèmía.

W języku wczesnego chrześcijaństwa, zwłaszcza w łacińskim przekładzie Pisma Świętego (Wulgata), adventus oznaczać zaczął przyjście Syna Bożego na świat przez wcielenie, a także Jego powrót na ziemię, który ma nastąpić przy końcu czasów (por. Dz 13, 24; Mt 24, 3. 7; 1 Tm 6, 14; Tt 2, 13; Jk 5, 7).

Pojawienie się okresu zwanego adwentem ma ścisły związek z wprowadzeniem w życie liturgiczne Kościoła uroczystości Narodzenia Pańskiego. A chociaż datuje się ona na rok mniej więcej 336 i wyznaczona została w Rzymie na dzień zimowego przesilenia (25 grudnia), kiedy to w cywilnym kalendarzu Rzymian przypadał obchód „Narodzin Słońca Niezwyciężonego" (Natalia Solis Invicti), to jednak nie poprzedzał jej w wiecznym mieście czas jakichś specjalnych przygotowań3 ${ }^{3}$ Stąd też początków takiego wstępu do uroczystości Bożego Narodzenia szukać należy gdzie indziej. Trzeba się mianowicie przenieść do Galii i Hiszpanii, gdzie faktycznie już pod koniec IV wieku występowało przygotowanie tego rodzaju ${ }^{4}$.

Gdy idzie o Galię, biskup Tours, Perpetuus († 490), wprowadził obowiązek postu w poniedziałki, środy i piątki w okresie następującym po dniu św. Marcina (11 listopada) aż do Bożego Narodzenia5 . Okres ten, nazwany 5, s. 9).

${ }^{2}$ Por. JAN PAwet II, Z „przestania” do Sesji Plenarnej i Dyscypliny Sakramentów (DPLiL

${ }^{3}$ Faktem zaskakującym i wartym szczególnego podkreślenia jest to, że adwent jako czas przygotowań do Bożego Narodzenia-zainicjowanego przecież w Rzymie - ma swój rodowód gdzie indziej. Por. A. Nocent, Panoramica storica dell'evoluzione dell'anno liturgico, [w:] Anàmnesis. Introduzione storico-teologica alla Liturgia, t. VI: L'anno liturgico: storia, teologia e celebrazione, red. A. J. Chupungco, Genova 1988, s. 48.

${ }^{4}$ Por. A. Nocent, Il tempo della manifestazione, [w:] Anàmnesis, t. VI, s. 193. 
„Quadragesima Sancti Martini”, trwał początkowo - jak się przypuszcza - do Objawienia Pańskiego i był związany z tradycyjnym udzielaniem chrztu 6 stycznia ${ }^{6}$. Był to więc czas przygotowawczy do sakramentów wtajemniczenia, podobnie jak czterdziestodniowy post przed Paschą ${ }^{7}$.

W Hiszpanii pierwsze świadectwa o ascezie przed obchodem Narodzenia Pańskiego (choć ten rodzaj przygotowań nie był tam jeszcze wyraźnie nazywany adwentem) pochodzą z roku 380. Kanon 4 synodu w Saragossie (380) polecał wiernym, aby od 17 grudnia do Epifanii gorliwie uczestniczyli w celebracjach liturgicznych, wyrzekając się na ten czas innych czynności. Wydaje się, że motywy kierujące taką decyzją były zbliżone do rozporządzeń biskupa Perpetuusa z Tours ${ }^{8}$.

W Rzymie natomiast, gdzie Boże Narodzenie obchodzone było po raz pierwszy, znacznie później wprowadzono okres poprzedzających je przygotowań. Najstarsze na ten temat źródła pochodzą z drugiej połowy VI wieku’. W Sakramentarzu z Werony (jego rękopis powstał w wieku VII, choć zebrane w nim formuły są z pewnością starsze) znajduje się 36 formuł modlitw na dni postu dziesiątego miesiąca ${ }^{10}$. Niektóre z nich zawierają wzmiankę o zbliżającym się święcie ${ }^{11}$. Nie ma tam jednak jeszcze określonej struktury ani nazwy czasu przygotowań do Bożego Narodzenia ${ }^{12}$. Pewnym zwiastunem rzymskiego adwentu były tzw. „suche dni zimowe” (środa, piątek i sobota tygodnia poprzedzającego przesilenie dnia z nocą w grudniu) ${ }^{13}$, gdy obowiązywała modlitwa i post. Według badań przeprowadzonych przez niektórych liturgistów, adwent

${ }^{5}$ Por. Grzegorz z Tours, Historia Francorum X, 31: „A depositione domni Martini usque ad Natale Domini terna in septimana ieiunia" (PL 71, 566).

${ }^{6}$ Wszystko wskazuje na to, że Epifania, która z całą pewnością ma początek na Wschodzie, świętowana była w Galii już w 361 r., a więc jeszcze przed przyjęciem się tam Bożego Narodzenia (od V w.). Świętowano ją mianowicie jako jeden z centralnych dni, w którym udzielany był sakrament chrztu. Por. B. NAdOLski, Liturgika, t. II: Liturgia i czas, Poznań 1991, s. 110.

${ }^{7}$ Por. S. Czerwik, Misterium Adwentu i Narodzenia Pańskiego na tle prefacji, „Liturgia Sacra” 2 (1996) nr 3-4, s. 6; A. Nocent, Panoramica storica..., s. 48; TENŻE, Il tempo..., s. 194; B. NADOLSKI, Liturgika, t. II, s. 110.

${ }^{8}$ S. Czerwik, Misterium Adwentu..., s. 6; A. Nocent, Panoramica storica..., s. 48; Tenże, Il tempo..., s. 194; B. NADOLSKI, Liturgika, t. II, s. 109-110.

${ }^{9}$ S. Burzawa, Adwent, Kraków 1994, s. 82; A. Nocent, Panoramica storica..., s. 48; TENŻE, Il tempo..., s. 194.

${ }^{10}$ Por. Sacramentarium Veronense (dalej Ve) XLIII, 1294-1330: In ieiunio mensi decimi (wyd. L. C. Mohlberg, Roma 1994³).

${ }^{11}$ Por. np. dwie prefacje: Ve 1297, a zwłaszcza Ve 1313 (ten tekst jest szczególnie interesujący we fragmencie: ,ut non solum terrena fertilitate laetemur, sed nativitete[m] panis aeterni purificatis suscipiamus mentibus honoranda[m]").

${ }^{12}$ Por. A. Nocent, Il tempo..., s. 196.

${ }^{13}$ Por. Tenże, Panoramica storica ..., s. 49. 
rzymski obejmował początkowo sześć tygodni ${ }^{14}$. Źródła podają pięć formularzy na niedziele adwentu oraz jeden (szósty), stosowany na zakończenie całonocnej wigilii w sobotę „suchych dni” (Dominica vacat) ${ }^{15}$.

\section{TEOLOGIA ADWENTU}

Od czasów Grzegorza Wielkiego (590-604) rzymski adwent obejmować zaczął cztery tygodnie ${ }^{16}$. W odróżnieniu od koncepcji obowiązującej Galów i Hiszpanów, gdzie przygotowanie do Narodzenia Pańskiego przybierało charakter pokutno-ascetyczny, w Rzymie adwent był początkowo czasem bezpośredniego, liturgicznego przygotowania na obchód pamiątki historycznego przyjścia Chrystusa, później zaś, to jest w ciągu XII wieku, nie tracąc swej pierwotnej charakterystyki wstępu do świąt Narodzenia Pańskiego, nabrał - szczególnie pod wpływem liturgii galijskiej - cech ascetyczno-eschatologicznych, co oznacza, że stał się również czasem przygotowania na ostateczne przyjście Chrystusa w chwale, a więc zaczął się odznaczać podwójnym wymiarem. Rzym zresztą trochę mocniej niż inne wspólnoty lokalne podkreślał centralne znaczenie Paschy w całym misterium zbawczym, upamiętnianym w sprawowanej liturgii. Stąd i Boże Narodzenie było tam rozumiane jako święto przygotowujące do obchodów Paschy, a nawet interpretowane jako swoisty jej początek ${ }^{17}$. Z drugiej zaś strony chrześcijanie Rzymu odznaczali się pogłębioną wrażliwością biblijną i jakby instynktownym wyczuciem teologicznym, koncentrującym ich uwagę i pobożność również na Bożym Narodzeniu. Wszystko to sprzyjało celebracji i przeżywaniu postawy oczekiwania w podwójnym wymiarze (na święto Narodzin i na chwalebną paruzję), zawsze jednak w symbiozie z misterium paschalnym, celebrowanym jako początek

${ }^{14}$ Por. A. Chavasse, Le Sacramentaire Gelasien, Paris 1957; H. Auf Der Maur, Feiern im Rhythmus der Zeit I. Herrenfeste in Woche und Jahr, [w:] Gottesdienst der Kirche. Handbuch der Liturgiewissenschaft, Teil 5, red. H. B. Meyer, Regensburg 1983, s. 180; A. Nocent, Il tempo..., s. 194; S. Burzawa, Adwent, s. 84-92.

${ }^{15}$ Taki system celebracji stosowany był przy wszystkich typach „suchych, lub inaczej kwartalnych, dni”, które do Soboru Watykańskiego II celebrowane były w czterech okresach roku, a mianowicie: suche dni Pięćdziesiątnicy - czas zbiorów; suche dni września - czas winobrania; suche dni grudnia, a konkretnie tygodnia poprzedzającego zimowe przesilenie dnia z nocą - czas zasiewu; suche dni postu, obchodzone początkowo przez cały Wielki Post, później zaś (począwszy od Sakramentarza Gelazjańskiego) w jednym tygodniu marca (por. GeV 140). Por. A. Nocent, Panoramica storica..., s. 49; S. Czerwik, Misterium Adwentu..., s. 7.

${ }^{16}$ Por. A. NocEnt, Il tempo..., s. 194. Sakramentarz Grzegorza Wielkiego (tzw. „Gregoriański”) zawiera już formularze na cztery niedziele adwentu oraz trzy Msze święte związane z kwartalnymi dniami zimowymi. Por. B. NADOLSKI, Liturgika, t. II, s. 110.

${ }^{17}$ Dlatego też Janowe nawoływanie cytatem z proroka Izajasza (por. Iz 40, 3) do przygotowania dróg Panu (por. Mt 3, 1-3; Mk 1, 2; Łk 3, 4), które współcześnie wiążemy $\mathrm{z}$ adwentem, odnoszono wówczas do przygotowania się na uroczystość Paschy. Por. B. NADOLSKI, Liturgika, t. II, s. 110. 
tryumfu Chrystusa nad złem ${ }^{18}$. Tak więc przygotowanie do Bożego Narodzenia ubogacone zostało w sposób całkiem naturalny i przyoblekło się w ten właśnie podwójny wymiar przygotowawczo-oczekujący. Dlatego i sam termin ,adventus" przeszedł w środowisku chrześcijan odpowiednią mutację i ze słowa o pogańskiej treści „przyjścia”, „przybycia” lub ich „rocznicy” przekształcił się w pojęcie o znaczeniu „oczekiwania” i ,przygotowania”. Jak więc początkowo „adventus” wskazywał na narodziny Pana i tych narodzin rocznicę, tak później podkreślać zaczął potrzebę przygotowania się do celebracji tego wydarzenia i w końcu oczekiwania na drugie, chwalebne przyjście Chrystusa ${ }^{19}$.

Oba te aspekty adwentu przyjęły się na skalę powszechną i są w jego liturgii przez Kościół wciąż przeżywane i aktualizowane. Adwent bowiem jest dla Kościoła „okresem przygotowania do uroczystości Narodzenia Pańskiego, przez którą wspominamy pierwsze przyjście Syna Bożego do ludzi. Równocześnie jest okresem, w którym przez wspomnienie pierwszego przyjścia Chrystusa kieruje się dusze ku oczekiwaniu Jego powtórnego przyjścia na końcu czasów. Z obu tych względów adwent jest okresem pobożnego i radosnego oczekiwania"20. Na pierwszy plan wysuwa się więc w okresie adwentu przygotowanie do Narodzenia Pańskiego, a następnie jego wymiar eschatologiczny. W liturgii kolejność ta jest odwrócona, ponieważ w pierwszej połowie adwentu podejmuje się motyw oczekiwania na paruzję, w drugiej zaś, tj. od 17 do 24 grudnia, zwraca się myśli wierzących na przygotowanie do Bożego Narodzenia (posiada ona własne teksty euchologijne na każdy dzień oraz osobną prefację) $)^{21}$. Tak więc Kościół, który zbiera się w adwencie na sprawowanie liturgii, aby umacniać w sobie postawę wyczekująca, przekonuje się wciąż na nowo o potrzebie ciągłego nawracania, a także umacnia swoją nadzieję.

\section{Formy pobożności ludowej w adwencie}

„Dyrektorium o pobożności ludowej i liturgii” podyktowane zostało potrzebą zaprezentowania organicznej refleksji nad zagadnieniem związków liturgii z pobożnością ludową. Jego autorom chodziło o przypomnienie

${ }^{18}$ Klasycznym tego przykładem może być św. Leon Wielki (osobiście nie poznał adwentu w Rzymie), który wraz z innymi ojcami Kościoła łączy przyjście Pana w Betlejem z Jego drugim adwentem przy końcu czasów. Dla Ojców Boże Narodzenie było już - poprzez ubóstwo żłóbka - świętem tryumfu, połączonym ściśle ze zbawczym zwycięstwem krzyża, jak i z ostatecznym tryumfem Chrystusa w chwili Jego chwalebnej paruzji. Por. A. Nocent, Il tempo..., s. 195.

${ }^{19}$ Por. J. Hild, L'Avent, „La Maison-Dieu” 1959, nr 59, s. 10-24; A. Nocent, Il tempo..., s. 195.

${ }^{20}$ Ogólne normy roku liturgicznego i kalendarza ogłoszone w motu proprio Pawła VI Mysterii paschalis celebrationem (10 II 1969), nr 39.

${ }^{21}$ Por. B. NAdOLSKI, Liturgika, t. II, s. 111. 
pewnych zasad, a także wskazań, jakie należy zachować przy praktycznym stosowaniu form tejże pobożności (zob. nr 3). Dokument ten nie przedstawia oczywiście wyczerpującej listy takich form i ludowych zwyczajów, kultywowanych w konkretnych miejscach, ani nie pragnie wzbudzić ducha „adopcjonizmu”, który by mobilizował do przejmowania i przystosowywania do własnych środowisk tych form pobożności „na siłę”. Zadaniem, jakie stawia sobie Dyrektorium, jest zaznajomienie nas ze sposobami pozaliturgicznego przeżywania i zgłębiania tajemnic wiary, przez rozwój praktyk pobożnościowych o charakterze prywatnym lub wspólnotowym. A choć dokument stara się również o zapobieżenie możliwym w niektórych przypadkach nadużyciom i dewiacjom, to jednak zachowuje w swej treści ton pozytywny, działając ku zbudowaniu ludu Bożego (zob. nr 4).

Na przestrzeni wieków Kościoły partykularne Zachodu w niejednakowy sposób znaczone były rozkwitem i zakorzenianiem się w ich wspólnotach zróżnicowanych sposobów wyrażania - w symbiozie z liturgią lub też równolegle do niej - wiary w Boga, miłości do Chrystusa Zbawiciela, otwarcia na Ducha Świętego, czci wobec Maryi Dziewicy i świętych, a także zaangażowania w nieustanne nawracanie się, w krzewienie braterskiej miłości (zob. nr 6) ${ }^{22}$ i chrześcijańskiej nadziei.

${ }^{22}$ Warto w tym miejscu zauważyć, że Dyrektorium, oprócz interesującego nas pojęcia „pobożności ludowej”, pod którym rozumie różne formy kultu o charakterze prywatnym lub wspólnotowym, manifestowane w środowisku wyznającym wiarę chrześcijańską, za pomocą wzorów wyrastających nie z liturgii, ale z geniuszu danego ludu lub jakiejś grupy etnicznej i jej kultury (zob. nr 9), wymienia jeszcze inne określenia, które na swój sposób odnoszą się również do zagadnień wyrazu wiary i chrześcijańskiej duchowości w sposób właściwy ludowi, a więc nie inspirowany oficjalnie przez Kościół. Pojęciami tymi są: 1) „nabożeństwo” („ćwiczenia pobożnościowe”) - publiczny lub prywatny wyraz pobożności chrześcijańskiej, który nie przynależąc do liturgii, pozostaje z nią w zgodzie, z niej czerpie inspirację i do niej w jakiś sposób prowadzi. Niektóre z tych ćwiczeń są spełniane z mandatu Stolicy Apostolskiej, inne z mandatu biskupa; liczne przynależą do tradycji kulturowych poszczególnych Kościołów partykularnych lub zgromadzeń zakonnych; posiadają zawsze odniesienie do publicznego Objawienia i tło eklezjalne; 2), ,zewnętrzne praktyki pobożności” - różne formy zewnętrzne (np. teksty modlitw i śpiewów; przestrzeganie określonych okresów i nawiedzanie miejsc szczególnych; medaliki, emblematy, szaty i zwyczaje), które w połączeniu z odpowiednim wewnętrznym przeżyciem wiary stanowią znak szczególnego związku wierzącego z Osobami Boskimi lub z Błogosławioną Dziewicą Maryją albo ze świętymi; 3) „religijność ludowa” - rzeczywistość dotykająca doświadczenia o charakterze ogólnym, a mianowicie zachodzącym w sercu każdego człowieka, utożsamiającym się z kulturą poszczególnych ludów i ich społecznym wyrazem. Każdy naród faktycznie zmierza do uzewnętrznienia swojego sposobu pojmowania rzeczywistości transcendentnej, a także natury stworzonej, społeczeństwa i historii. Uzewnętrznienia tego dokonuje za pomocą czynników kultycznych, tworzących jakby syntezę o wielkim znaczeniu humanitarnym i duchowym. Niekoniecznie musi się wiązać z Objawieniem przyjmowanym przez chrześcijan (często łączy się z innym systemem religijnym - np. z buddyzmem), ale kiedy się już wyraża w społeczności o jakimś (większym 
Takim rozkwitem odznaczał się praktycznie cały rok życia kościelnego, a w tych ramach również adwent obchodzony jest liturgicznie jako (zob. DPLiL 96):

- oczekiwanie-pamiątka pierwszego ,adwentu” Zbawiciela w naszym ludzkim ciele oraz jako oczekiwanie-prośba, mająca za przedmiot ostateczne, chwalebne przyjście Chrystusa - Pana czasu i Sędziego;

- nawrócenie, do którego adwentowa liturgia często nawołuje głosem proroków, zwłaszcza zaś ustami Jana Chrzciciela („Nawracajcie się, bo bliskie jest królestwo niebieskie" - Mt 3, 2);

- radosna nadzieja, że wysłużone już przez Chrystusa zbawienie (por. Rz 8, 24-25) i rzeczywistość przyszłej chwały, już w stanie łaski obecna w tym świecie, osiągną swą doskonałość, a dzięki niej obietnica przekształci się w rzeczywiste posiadanie, wiara - w oglądanie „twarzą w twarz” i wszyscy staniemy się „do Niego podobni, bo ujrzymy Go takim, jakim jest" (1 J 3, 2).

Rozwój pobożności ludowej przybrał na sile w średniowieczu, kiedy to powstały i rozwinęły się liczne jej formy, z których wiele dotrwało w jak najlepszej kondycji do naszych czasów. Należy przy tym wypunktować:

- poezję w językach ojczystych, ułatwiającą wiernym wniknięcie w misteria celebrowane w kościołach (w języku łacińskim);

- formy pobożności alternatywne lub paralelne w stosunku do celebracji liturgicznych, jak adoracje Najświętszego Sakramentu (miały one wynagradzać Bogu zbyt rzadkie przystępowanie do komunii świętej) czy różaniec (zastępował on niejako liturgię godzin);

- rosnącą cześć dla Maryi Dziewicy i świętych (rozwój pielgrzymek, kult relikwii, popularność modlitw litanijnych, kult zmarłych);

- liczne ryty błogosławieństw;

- święte okresy o podłożu ludowym, zachowywane jakby na marginesie roku liturgicznego (tridua, oktawy, nowenny, miesiące poświęcone szczególnym rodzajom pobożności);

- święte spektakle, poświęcone wydarzeniom zbawczym, obchodzonym w ciągu roku liturgicznego, między innymi przedstawienia związane z Bożym Narodzeniem (zob. DPLiL 32).

Pobożność ludowa przejawia również wyraźne wyczulenie na atmosferę adwentu. Uwrażliwia mianowicie wiernych na adwent jako czas pamiątki przygotowań na historyczne przyjście Mesjasza. W ludzie chrześcijańskim zakorzeniona

lub mniejszym) stopniu nasycenia wiarą chrześcijańską, to daje początek pewnemu rodzajowi „katolicyzmu ludowego”, w którym bardziej lub mniej harmonijnie współistnieją ze sobą elementy pochodzące z życia posiadającego sens religijny, z kultury właściwej danej społeczności oraz z Objawienia. Zob. DPLiL 7, 8, 10. Por. I. M. CAlabuig, Criteri ispiratori del „Direttorio su pietà popolare e liturgia”, „Rivista Liturgica” 89 (2002) nr 6, s. 915-916. 
jest mocno świadomość długotrwałego oczekiwania, jakim poprzedzone były te święte narodziny. Poświadcza on swą wiarę, że to sam Bóg za pośrednictwem proroków podtrzymywał w Izraelu nadzieję na przyjście Zbawcy.

Pobożności ludowej, która stara się dogłębnie wniknąć w czas tamtego adwentu, nie wymyka się jednak wymiar nadzwyczajności wydarzenia z Betlejem, a nawet nie kryje ona podziwu, że oto Bóg chwały stał się jednym z nas poprzez łono skromnej i biednej Panny z małego miasteczka. Pobożny lud wykazuje szczególną wrażliwość na trudności, w jakich znalazła się wtedy Maryja i jakim stawić musiała czoło, a także wzrusza się do łez na myśl o tym, że w betlejemskiej gospodzie zabrakło noclegu dla Brzemiennej i Jej świętego Opiekuna (por. Łk 2, 5. 7).

Tę wrażliwość $\mathrm{w}$ adwencie podtrzymują w wiernych różne formy pobożności, które wzmacniają ich wiarę i dzięki którym wartościowe cechy tego okresu liturgicznego mogą być przekazywane następnym pokoleniom (zob. DPLiL 97). Omawiane Dyrektorium wymienia ich sześć. Są to: wieniec adwentowy (nr 98); procesje adwentowe (nr 99); suche (kwartalne) dni zimowe (nr 100); cześć dla Maryi w adwencie (nr 101); nowenna przed Bożym Narodzeniem (nr 103); szopka (nr 104).

Spróbujmy te formy prześledzić, wydobywając z nich całe duchowe bogactwo, jakim w adwencie karmią one wiernych, idących na spotkanie z Panem, który nadchodzi, oraz przygotowujących się do sprawowania pamiątki w dorocznym liturgicznym obchodzie Bożego Narodzenia.

\section{WIENIEC ADWENTOWY}

Zwyczaj zawieszania wieńca adwentowego (niem.Adventkranz) w kościele nie należy do najstarszych. Pojawił się bowiem w 1833 roku w Niemczech i rozprzestrzenił szybko w Ameryce Północnej. Jego inicjatorem był teolog i działacz społeczny, protestant Jan Henryk Wichern z Hamburga ${ }^{23}$. Zwyczaj ów polega na tym, że na wieńcu splecionym z zielonych gałązek jodłowych umieszcza się cztery świece, by następnie wieniec taki umieścić (zawiesić) w okolicach głównego ołtarza. W kolejne niedziele adwentu zapala się w wieńcu odpowiadającą im ilośćświec. Po roku 1945 zwyczaj ten zaczął się rozpowszechniać na terenach Austrii, Węgier, trafiając też do Polski ${ }^{24}$. Ostatnio można się z nim spotkać również we Włoszech oraz w innych krajach Europy. W adwencie roku 2002 wieniec taki (o odpowiednich rozmiarach) trafił na Placśw. Piotra i jeszcze po Bożym Narodzeniu można go było oglądać opodal szopki, ze zgaszonymi już co prawda świecami, ale też stopień ich wypalenia świadczył o tym, że zapalano

\footnotetext{
${ }^{23}$ B. NADOLSKI, Liturgika, t. II, s. 113.

${ }^{24}$ Por. J. Stefański, Liturgia dla każdego, Gniezno 1995, s. 77.
} 
je w kolejne niedziele adwentu. Popularność wieńca adwentowego wydaje się wciąż przybierać na sile, o czym świadczy fakt zawieszania go również (lub umieszczania na stole) w domach chrześcijan.

Sens tego zwyczaju jest jak najbardziej uzasadniony biblijnie. Cztery świece symbolizują cztery niedziele liturgicznego okresu oczekiwania. Zapalane kolejno, w prosty sposób ułatwiają wchodzącym do kościoła wiernym orientację, która niedziela adwentu jest aktualnie obchodzona, by przez to zwrócić ich uwagę na przemijalność czasu, na zbliżające się spotkanie z Panem ${ }^{25}$ oraz na konieczność przygotowania się na ten dzień przez pokutę i nawrócenie (na bliskość Pana wskazuje już samo umiejscowienie wieńca adwentowego przy ołtarzu, symbolizującym Chrystusa).

Kiedy tak, niedziela po niedzieli, aż do samych świąt lud zapala kolejną świecę adwentowego wieńca, to łatwiej mu przeżywać pamiątkę poszczególnych etapów zbawczej historii przed narodzeniem Chrystusa oraz symbolikę owej profetycznej światłości, która stopniowo rozjaśniała mroki czasu oczekiwań aż do dnia, w którym z wysoka wschodzące Słońce nawiedziło swój lud, zajaśniało i świeci wszystkim, co w mroku i cieniu śmierci mieszkają, aby kroki wszystkich zwrócić na drogę pokoju (por. Łk 1, 78-79; Ml 3, 20). Oprócz symboliki światła, jest w adwentowym wieńcu również symbolika związana z nadzieją i życiem. Wskazuje na to zieleń gałązek jodły. Zieleń to kolor nadziei ${ }^{26}$, to ekspresja pragnienia, by uczestniczyć wraz z Jezusem w chwale; zieleń to symbol życia, które przynosi w nas dobry owoc. Sam Jezus zastosował symbol zieleni do siebie samego, gdy schodząc ze świata w pełni swych ludzkich lat, porównał się z zielonym drzewem, które mogłoby obficie owocować (por. Łk 23, 31)27. Gałązki jodłowe nasuwają myśl o gałązkach winnego krzewu, czyli o ewangelicznych latoroślach (są nimi wierzący w Chrystusa), które pulsują życiem tylko wtedy, gdy są wszczepione w winny krzew i gdy w nim trwają (krzewem tym jest Jezus Chrystus - por. J 15, 4-5). Wymowny jest również sam kształt wieńca adwentowego: krąg to obraz kochającej się wspólnoty, która z radością oczekuje na swego Pana ${ }^{28}$.

\section{PRocesje ADWENTOWE}

W pewnych regionach odbywają się przez adwent różnego rodzaju procesje, które obwieszczają wszem i wobec (przechodzą bowiem ulicami

${ }^{25}$ Por. L. M. Lechner, Advent, cz. 3: Volkskunde, LThK, t. I, kol. 161.

${ }^{26}$ Por. J. AldazÁBAL, Simboli e gesti. Significato antropologico biblico e liturgico, Torino 1988, s. 49. Zob. też hasło „Zieleń” [w:] Leksykon symboli, oprac. M. Oesterreicher-Mollwo, Warszawa 1992, s. 183; D. Forstner, Świat symboliki chrześcijańskiej, Warszawa 1990, s. 122.

${ }^{27}$ Por. K. Romaniuk, A. Jankowski, L. Stachowiak, Komentarz praktyczny do Nowego Testamentu, t. I, Poznań-Kraków 1999, s. 405.

${ }^{28}$ B. NADOLSKI, Liturgika, t. II, s. 113. 
osiedli i wiosek) nadchodzące Narodziny Syna Bożego. Taki charakter mają procesje zwane „chiara stella” (jasna gwiazda), organizowane w niektórych rejonach Włoch. W Ameryce Południowej i niektórych dzielnicach Hiszpanii napotkać można procesje zwane „le posadas” (la posada-dom, gospoda), w których odtwarza się drogę Józefa i Maryi z Nazaretu do Betlejem i poszukiwanie przez nich gościnnego dachu nad głową dla godnych narodzin Jezusa. Zaczyna się to w kościele parafialnym, skąd po modlitwach wyrusza procesja, by przejść wyznaczoną trasą. Idący w niej „św. Józef" puka do kolejnych drzwi, ale wszystkie są pozamykane. Na koniec procesja dociera do dużej hali, gdzie wreszcie - po wcześniejszym pukaniu „Św. Józefa” - podwoje się otwierają, a radość napełnia nie tylko „Maryję", która w procesji idzie obok swego Oblubieńca, ale też całą miejscową wspólnotę, dzielącą z nimi tę radość aż do rana ${ }^{29}$.

\section{SUCHE DNI ZIMOWE}

Suche dni, których współczesna łacińska nazwa to „Quartor anni tempora”, nosiły pierwotnie nazwe „Ieiunium mensis (primi) quarti, septimi, decimi", a więc chodzi o post miesiąca czwartego, siódmego i dziesiątego, a od VI wieku również pierwszego (marca). W VIII wieku przyjęła się nazwa „Quattuor tempora”. Tę nazwę stosuje większość języków europejskich. Również i w języku polskim pojawiają się niekiedy „kwartalne dni modlitw" (otwarcie kwartałów).

Suche dni zimowe (których czas przypada na środę, piątek i sobotę trzeciego tygodnia adwentu) wskazują na przesilenie się pór roku oraz na okres wypoczynku i spokoju w licznych dziedzinach ludzkiego życia i jego aktywności. Pobożność ludowa odznacza się zawsze szczególnym uwrażliwieniem na rytm przyrody. Zimą, kiedy obchodzi się te dni, ziarno wrzucone w ziemię drzemie w niej, oczekując na światło i ciepło słoneczne, zaś słońce od momentu przesilenia zimowego zaczyna się wzbijać coraz wyżej, aż w miesiącach letnich dojdzie do punktu, który zapewni uśpionym zimą ziarnom rozkwit i dojrzenie do żniwa.

W niektórych środowiskach pobożność ludowa wpłynęła na powstanie specjalnych nabożeństw związanych z zimowym przesileniem. W diecezjach polskich zaleca się na trzeci tydzień adwentu „kwartalne dni modlitw o życie chrześcijańskie w rodzinach" ${ }^{30}$. W myśl Dyrektorium nabożeństwa

${ }^{29}$ Por. J. Stefański, Liturgia..., s. 78.

${ }^{30} \mathrm{Na}$ inne zaś kwartały zalecenia są następujące: 1 ) od Środy Popielcowej do pierwszej niedzieli Wielkiego Postu - dni modlitw o ducha pokoju; 2) w czwartym tygodniu Wielkanocy - dni modlitw o powołania do służby w Kościele; 3) w trzecim tygodniu września - za młodzież, dzieci i wychowawców; 4) od szóstej niedzieli do środy przed uroczystością Wnie- 
te powinny być zachowane i dowartościowane, stając się okazją do tego, aby kierować się do Boga w szczególnych intencjach, aby przeżywać refleksję nad znaczeniem ludzkiej pracy, aby ją pojmować jako współpracę człowieka z Bogiem w dziele stworzenia, jako samourzeczywistnianie się osoby ludzkiej, jak również jako służbę na rzecz dobra wspólnego i aktualizację zbawczego planu (por. KDK 34, 35, 67).

\section{CZEŚĆ DLA MARYI W ADWENCIE}

Liturgia adwentowego oczekiwania odwołuje się często do przykładu Błogosławionej Dziewicy ${ }^{31}$, wspominając też niektóre z wielkich niewiast Starego Testamentu jako figury Matki Bożej; wychwala postawę wiary i pokory, jaką przyjęła Maryja z Nazaretu, odpowiadając na zbawczy Boży plan, przekazany Jej przez anioła; w liturgii podkreśla też Kościół Jej obecność w tych wydarzeniach, które poprzedziły narodzenie się Zbawiciela. Również pobożność ludowa zwraca w tym czasie szczególną uwagę na Jej postać, o czym świadczą odprawiane w adwencie nabożeństwa, a szczególnie dwie nowenny: przed Niepokalanym Poczęciem i przed Bożym Narodzeniem. Dowartościowanie adwentu ,jako czasu szczególnie nadającego się do uczczenia Matki naszego Pana”32 nie oznacza oczywiście, że można ten okres potraktować jako „miesiąc Maryjny" (DPLiL 101), bo ma to być czas uczenia się od Niepokalanej Dziewicy czynnej postawy w oczekiwaniu adwentowym.

Okolicznością sprzyjającą rozwojowi kultu maryjnego w adwencie jest obchodzona w grudniu uroczystość Jej Niepokalanego Poczęcia ${ }^{33}$, bardzo ważna dla wiernych. Ona to właśnie dała początek różnym formom maryjnej pobożności, wśród których szczególne znaczenie ma nowenna przed 8 grudnia. Nie ulega wątpliwości, że treść takiego obchodu liturgicznego, który ukazuje Maryję jako czystą i bez zmazy, bardzo dobrze przystaje - w perspek-

\footnotetext{
bowstąpienia - dni modlitw o urodzaje. Reforma kalendarza po Soborze Watykańskim II określa sens kwartalnych dni modlitw jako porę próśb w różnych potrzebach ludzi, zwłaszcza o dobre urodzaje, o błogosławieństwo w pracy, oraz jako dni publicznego dziękczynienia. Dni te winny być dostosowane do kultury różnych krajów i ludów. Konferencje poszczególnych episkopatów winny ustalić datę ich obchodu i długość. Teksty mszalne należy wybrać z zestawu Mszy w różnych potrzebach, zgodnie z charakterem danych dni (ONRLK 45-46). Por. B. NADOLSKI, Liturgika, t. II, s. 25.

${ }^{31}$ Por. PAweŁ VI, Adhortacja apostolska Marialis cultus, Rzym 2 II 1974, nr 4.

${ }^{32}$ Tamże.

${ }^{33}$ Choć dogmat o niepokalanym poczęciu Maryi ogłosił papież Pius IX w 1854 r. (bullą Ineffabilis Deus), to jednak święto Niepokalanego Poczęcia Kościół katolicki obchodzić zaczął za czasów papieża Sykstusa IV († 1484). Od pontyfikatu papieża Klemensa XI (†1721) stało się ono świętem nakazanym, a Leon XIII († 1903) nadał mu rangę pierwszej klasy. Pius X († 1914)w reformie liturgicznej podtrzymał tę jego pozycję. Ostatnia zaś reforma kalendarza liturgicznego (1969) nadała temu świętu rangę uroczystości. Por. W. ZALESKI, Rok kościelny, Warszawa 1989, s. 31.
} 
tywie przygotowań do Bożego Narodzenia - do głównych tematów adwentu, takich jak samo oczekiwanie na Mesjasza czy zapowiadające Go proroctwa Starego Testamentu, które również są obecne w liturgii adwentowej. Proroctwa te obejmują łuk czasowy, wsparty z jednej strony na uroczystym orzeczeniu Księgi Rodzaju (3, 15), z drugiej zaś na pozdrowieniu archanioła Gabriela, który nazwał Ją „pełną łaski” (Łk 1, 28) i zapowiedział narodziny Syna Bożego (por. Łk 1, 31-33).

Wielką popularnością cieszy się również na kontynencie amerykańskim święto Matki Bożej z Gwadelupy, obchodzone przed Bożym Narodzeniem, 12 grudnia. Dobrze przygotowuje ono wiernych na przywitanie Zbawcy, ponieważ uczy czcić Maryję jako ściśle zjednoczoną z narodzinami Kościoła w Ameryce i jako Gwiazdę, która przyświecała głoszeniu Chrystusa-Zbawiciela synom mieszkających tam ludów ${ }^{34}$.

\section{NOWENNA PRZED BOŻYM NARODZENIEM}

Nowenna przed Bożym Narodzeniem powstała dla umożliwienia wiernym przekazu tych teologicznych bogactw liturgii, z których niełatwo im było czerpać ze względu na porę sprawowania liturgii i odległości dzielące ich od kościołów. Nowenna ta odegrała ważną rolę w kształtowaniu duchowości wiernych i jak najbardziej w dalszym ciągu powinna ją pełnić. Niemniej w dobie obecnej, kiedy to ułatwiony został udział ludu w celebracjach liturgicznych, byłoby rzeczą pożądaną, aby w dniach od 17 do 23 grudnia (dni odprawiania nowenny) dowartościowana została celebracja nieszporów, wraz z ich „wielkimi antyfonami” ${ }^{35}$. Byłoby to okazją, aby dowartościować niektóre elementy pobożności ludowej, i stanowiłoby piękną „,nowennę przed Bożym Narodzeniem", posiadającą charakter celebracji liturgicznej, wrażliwej na potrzeby pobożności ludu, bowiem już w ramach nieszporów przewidziane są pewne elementy, które takim potrzebom mogą doskonale wyjść naprzeciw. Elementami tymi są: homilia, użyte kadzidło oraz modlitwa wstawiennicza, którą można dostosować do potrzeb wspólnoty (zob. DPLiL 103).

${ }^{34}$ JAN PAWEŁ II, Przemówienie na „Anioł Pański” z 24 stycznia 1999 w Città del Messico (zob. DPLiL 102).

${ }^{35}$ Dla drugiej części adwentu charakterystyczne są - począwszy od IX w. - tzw. , antyfony O” (wielkie antyfony). Noszą taką nazwę, ponieważ wszystkie rozpoczynają się od litery „O” ( O Sapientia”, „O Adonai”, „O Radix Jesse”, „O Clavis David”, „O Oriens”, „O Rex gentium”, „O Emmanuel”). Oparte są one na obrazach i symbolach biblijnych. W tłumaczeniu polskim stanowią one siedem kolejnych zwrotek dawno śpiewanej pieśni „Mądrości, która z ust Bożych wypływasz”. Ich treść obrazuje tęsknotę bogobojnych Izraelitów za Mesjaszem. Por. T. SinKA, Liturgika, Kraków 1994, s. 118. 


\section{SZOPKA}

Najstarsze z artystycznych wyobrażeń żłóbka spotykamy już na niektórych sarkofagach z IV i V wieku ${ }^{36}$. Od najdawniejszych czasów (podanie głosi, że w V wieku żłóbek Pana Jezusa został przeniesiony z Betlejem do Rzymu, gdzie go umieszczono w Bazylice Matki Bożej Większej) mamy też do czynienia w Rzymie z ustawianiem szopki betlejemskiej na celebrację mszy świetej zwanej „pasterką”. Jednak rozpowszechnienie zwyczaju budowania szopek w kościołach, a także w domach chrześcijan zawdzięczamy św. Franciszkowi, który osobiście uczynił to po raz pierwszy w miejscowości Greccio w roku 1223. Na szczególną uwagę zasługują szopki ustawiane w domach. Bywają one różnej wielkości. Niekiedy są małe, odpowiadające rozmiarom stołu lub szafki, na których się je ustawia. Kiedy indziej są większe, a bywa nawet, że zajmują znaczną część jednego pokoju. Ich przygotowanie wymaga odpowiednich nakładów czasu, inwencji (przeważnie nie powtarza się tego samego wzoru), a także ciężkiej pracy wielu osób. Tak to okres adwentu spędzają całe rodziny na realizacji wspólnego przedsięwzięcia, a przez to ich członkowie mogą czuć się mocniej ze sobą zespoleni wokół misterium narodzin Pana. Przygotowując bowiem szopkę w domu, nie tylko wykonują potrzebne prace, ale też czytają wspólnie i rozważają teksty biblijne o narodzeniu Jezusa w Betlejem. W taki sposób czas adwentu staje się czasem biblijnej lektury, refleksji i wspólnej modlitwy, dobrze usposabiając serca wszystkich domowników na przyjście Oczekiwanego.

W następstwie zainicjowanej przez Sobór Watykański II odnowy kościelnej, pobożność ludowa trafia na bardzo różnorodny grunt, w zależności od kraju, w jakim występuje, albo od zakorzenionych tam zwyczajów lokalnych. W stosunku do form pobożności ludowej dostrzega się rozmaity, często przeciwstawny sobie, sposób reagowania (zob. DPLiL 1):

- w niektórych sytuacjach doszło do najzwyklejszego porzucenia form odziedziczonych z przeszłości, co powoduje pustkę nie zawsze możliwą do zapełnienia ${ }^{37}$;

- w pewnych środowiskach dostrzega się przesadne przywiązanie do niedoskonałych, a nawet błędnych form pobożności, które niestety oddalają od prawdziwych treści Objawienia i stanowią pewnego rodzaju konkurencję dla życia sakramentalnego;

${ }^{36}$ J. STEFAŃSKi, Liturgia..., s. 84.

${ }^{37}$ Por. M. Mignone, La pietà popolare in Avvento, „Rivista di Pastorale Liturgica” 13 (1976) nr 6, s. 44. 
- bywają też nieuzasadnione głosy krytyki wobec pobożności tego typu, wypowiadane w imię tzw. „obrony czystości wiary”, jak również przeciwstawiający się im mocno postulat zachowania omawianych form, jako sposobu czucia przez chrześcijan ich wiary w określonym czasie i miejscu;

- podnosi się potrzebę oczyszczenia pobożności ludowej ze wszystkiego, co budzi dwuznaczność i co ociera się o niebezpieczeństwo tzw. synkretyzmu, czyli poplątania różnych, sprzecznych wobec siebie elementów religijnych, z mitologicznymi i zabobonnymi;

- dostrzega się nieraz ożywienie pobożności ludowej jako postać odreagowania na kulturę techniczno-pragmatyczną i na ekonomiczny utylitaryzm;

- można w końcu dostrzec postawę braku zainteresowania pobożnością ludową, co jest spowodowane szerzącym się dziś sekularyzmem albo napływem sekt, wrogo nastawionych do pobożności ludowej.

Dzięki swemu niepowtarzalnemu walorowi, jakim odznacza się zjawisko pobożności ludowej, a mianowicie dzięki intuicyjnemu wyczuciu głębi i bogactwa misterium sprawowanego przez Kościół, pobożność ta może wnieść ogromny wkład w zachowanie niektórych wartości adwentu, zagrożonych w naszych czasach przez silnie lansowany w mediach i reklamie model konsumistycznego podejścia do świata, co ma swoje konsekwencje w niewłaściwym przeżywaniu adwentu (zob. DPLiL 105).

Pobożność ludowa daje świadectwo naturalnej umiejętności zdrowego wyczucia i przekonania, że Boże Narodzenie można w godny sposób przeżywać tylko w klimacie umiarkowania, prostoty i solidarności z ludźmi biednymi oraz potrzebującymi. Pobożność ta czyni nasze adwentowe oczekiwanie wrażliwszym na dar życia, na obowiązek szanowania go i obrony w razie zagrożeń. Poucza nas także o tym, iż pamiątki narodzin Pana, który „zbawia swój lud od jego grzechów" (Mt 1,21), nie sposób obchodzić godnie, jeżeli się nie chce podjąć wysiłku wyzwolenia z nich, by żyć w czujnym oczekiwaniu na Tego, który powróci przy końcu czasów (zob. DPLiL 105). Stąd Kościół ma ważne zadanie przychylnego odnoszenia się do różnych form pobożności ludowej, a także roztropnego rozeznawania ich wartości i przydatności dla duchowego dobra chrześcijan.

Katowice

KS. ANDRZEJ ŻĄDEO 


\section{Riassunto}

La liturgia e le forme della pietà popolare nell'Avvento alla luce del „Direttorio su pietà popolare e liturgia"

Il 17 dicembre del 2001 la Congregazione per il Culto Divino e la Disciplina dei Sacramenti ha promulgato il „Direttorio su pietà popolare e liturgia”. In aprile del 2002 questo direttorio è stato pubblicato in lingua italiana, invece nel 2003 è apparsa la sua traduzione in lingua polacca, presa in elaborazione nell'articolo sopra presentato.

Il contenuto dell'articolo è dedicato alla questione della pietà popolare nel tempo di Avvento, quindi alla problematica discussa nel quarto capitolo del documento preso in esame. Tale problematica viene accompagnata, nella prima parte dell'articolo, da uno sguardo d'insieme dedicato allo sviluppo storico di Avvento e alla sua teologia. Nella seconda parte dell'articolo vengono presentate le forme della pietà popolare sviluppatesi e praticate nel menzionato tempo liturgico dell'attesa della nascita di Gesù (esse sono: la corona e le processioni di Avvento, le „tempora d'inverno”, la Vergine Maria nell'Avvento, la novena del Natale, il presepio). In questa parte dell'articolo viene messa in evidenza la potenziale ricchezza spirituale di tali forme, ma anche la necessità dell'adeguato approfondimento teologico di esse e della loro evangelizzazione, per garantirne il giusto rapporto con la liturgia che costituisce il naturale coronamento delle forme di pietà popolare. E' importante che i pii esercizi del popolo cristiano rimangano vivamente raccomandati. E' ugualmente necessario però che tali esercizi vengano regolati in modo da rimanere in armonia con la sacra liturgia. La pietà popolare deve in qualche modo trarre ispirazione dalla liturgia e ad essa condurre il popolo cristiano (cfr. LG 13). 